
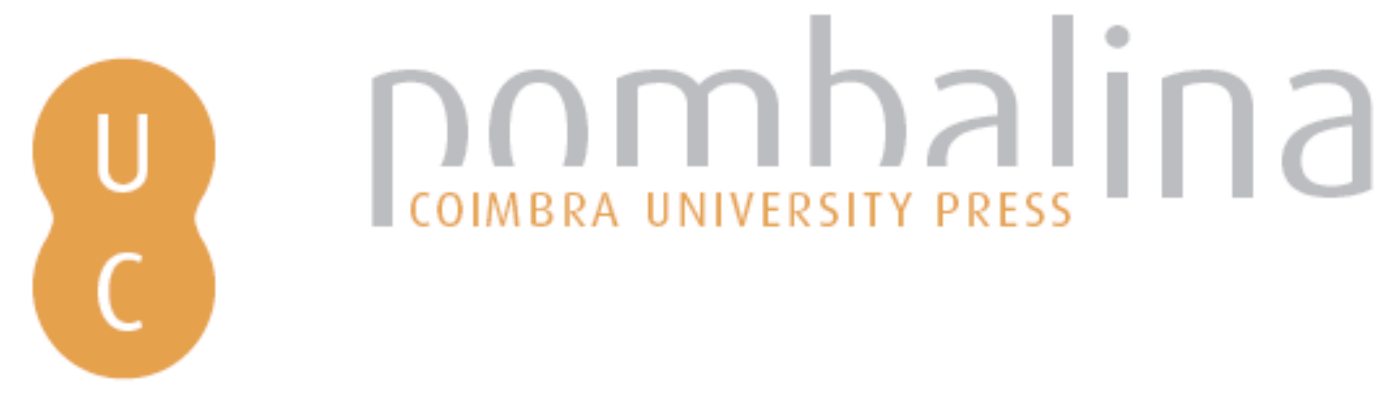

\title{
Architecture as a work of art and the sense of the historical whole an introduction to Le Corbusier, History and Tradition
}

Autor(es): Rabaça, Armando

Publicado por: Imprensa da Universidade de Coimbra

URL

persistente: URI:http://hdl.handle.net/10316.2/41604

DOI: $\quad$ DOI:https://doi.org/10.14195/978-989-26-1338-3_1

Accessed : $\quad$ 26-Apr-2023 14:40:17

A navegação consulta e descarregamento dos títulos inseridos nas Bibliotecas Digitais UC Digitalis, UC Pombalina e UC Impactum, pressupõem a aceitação plena e sem reservas dos Termos e Condições de Uso destas Bibliotecas Digitais, disponíveis em https://digitalis.uc.pt/pt-pt/termos.

Conforme exposto nos referidos Termos e Condições de Uso, o descarregamento de títulos de acesso restrito requer uma licença válida de autorização devendo o utilizador aceder ao(s) documento(s) a partir de um endereço de IP da instituição detentora da supramencionada licença.

Ao utilizador é apenas permitido o descarregamento para uso pessoal, pelo que o emprego do(s) título(s) descarregado(s) para outro fim, designadamente comercial, carece de autorização do respetivo autor ou editor da obra.

Na medida em que todas as obras da UC Digitalis se encontram protegidas pelo Código do Direito de Autor e Direitos Conexos e demais legislação aplicável, toda a cópia, parcial ou total, deste documento, nos casos em que é legalmente admitida, deverá conter ou fazer-se acompanhar por este aviso.

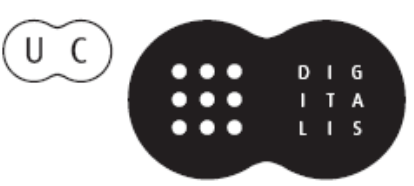


Ivan Zaknic

Arthur Rüegg

David Leatherbarrow

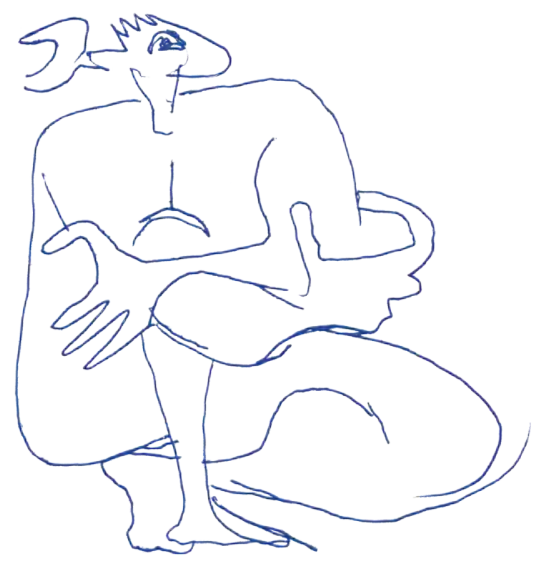

Christoph Schnoor

Francesco Passanti

Johan Linton

Stanislaus von Moos

Maria Candela Suárez

\section{Le Gorbusier}

\section{HISTORY TRADITION}

Edited by

Armando Rabaça 


\title{
Arghitegture as a Work of Art And the
}

\section{Sense of the HistoriaAl Whole}

\author{
an introduction to \\ Le Corbusier, History and Tradition
}

I had a feeling, which became positively overpowering and could not find wonderful enough utterance, that the past and the present were one. I saw them in a way that brought something ghostly into the quality of the present. This feeling is expressed in many of my larger and smaller works, and always has a beneficial effect in my poems, although at the actual moment of direct expression in life it was bound to appear strange, inexplicable and perhaps even unpleasant to the reader.

Goethe (Dichtung und Wahrheit)

Tradition ... involves, in the first place, the historical sense ... and the historical sense involves a perception, not only of the pastness of the past, but of its presence; the historical sense compels a man to write not merely with his own generation in his bones, but with a feeling that the whole of the literature of Europe from Homer and within it the whole of the literature of his own country has a simultaneous existence and composes a simultaneous order. This historical sense, which is a sense of the timeless as well as of the temporal and of the timeless and of the temporal together, is what makes a writer traditional. And it is at the same time what makes a writer most acutely conscious of his place in time, of his own contemporaneity ... 
No poet, no artist of any art, has his complete meaning alone. His significance, his appreciation is the appreciation of his relation to the dead poets and artists . . what happens when a new work of art is created is something that happens simultaneously to all the works of art which preceded it. The existing monuments form an ideal order among themselves, which is modified by the introduction of the new (the really new) work of art among them. The existing order is complete before the new work arrives; for order to persist after the supervention of novelty, the whole existing order must be, if ever so slightly, altered; and so the relations, proportions, values of each work of art toward the whole are readjusted; and this is conformity between the old and the new. ... the past should be altered by the present as much as the present is directed by the past.

... He [the poet] must be quite aware of the obvious fact that art never improves, but that the material of art is never quite the same. He must be aware that the mind of Europe - the mind of his own country - . . is a mind which changes, and that this change is a development which abandons nothing en route ... But the difference between the present and the past is that the conscious present is an awareness of the past in a way and to an extent which the past's awareness of itself cannot show ... [The poet] is not likely to know what is to be done unless he lives in what is not merely the present, but the present moment of the past, unless he is conscious, not of what is dead, but of what is already living.

\section{T. S. Eliot ("Tradition and the Individual Talent")}

Look at any building you like, as remote as you like from consciousness of aesthetic purposes, and you will notice how as soon as a choice of alternatives comes before the builder he inevitably conforms to some dimly perceived tradition of formal arrangement. There is no escape.

$$
\text { John Summerson (“The 'Poetry'of Le Corbusier") }
$$


While in certain academic circles the anti-historical bias of the Modern Movement still presents few riddles, the view of modernism as representing an epistemological break between technology and history and tradition has long been challenged. The influence of the past is recognizable in, for example, the blending of classicism and organicism in Alvar Aalto's work, the legacy of Dutch town houses in Pieter Oud's domestic architecture, and the composition of Mies van der Rohe's buildings. ${ }^{1}$ In Le Corbusier's work, however, this influence can be seen on the most abstract level. Le Corbusier's assimilation of the past is shaped by his creative process which, as John Summerson had already noted in the 1940s, is comparable to the processes of avant-garde poets and painters: his experimental architecture resulted from subverting the logic of every situation, bringing different fragments together and fusing them in a new synthesis. Summerson's comparison was made with specific reference to Picasso's belligerent process of creation through destruction and subsequent transformation in order to achieve "a more substantial result and profound possession of form." "Just as in a painting by Picasso, Braque or Léger the appearance of a thing is torn to pieces, broken into bits and reconstituted in a ridiculous jigsaw which has, nevertheless, a perfect logic of its own," Summerson writes, "so a building by Le Corbusier is a ruthless dismemberment of the building programme and a reconstitution on a plane where the unexpected always, unfailingly, happens. Herein is Le Corbusier's poetry - or his wit."”3

This comparison with avant-garde abstract art involves issues of form. For Summerson, for example, the tension in Le Corbusier's plans is comparable to that of Picasso's drawings. ${ }^{4}$ More than a problem of form, however, the similarities concern a fundamental problem of method and attitude towards the creative process. It is the interaction between this creative process and the past that would seem to explain why Le Corbusier's work has proved to be an inexhaustible reference point in the debate on the relationship between modern architecture, history and tradition.

In fact, underlying the modernist "creation through destruction" is a deep historical consciousness that was common to Le Corbusier and his 
modern contemporaries. He shared the same sense of the historical whole that can be found in T. S. Eliot's view of the new in artistic creation as the coexistence of past and present. The search for unity of past and present was translated into modern art through various aesthetic principles. Two aspects in particular are worth noting. On the one hand, the creation of the new implied the abandonment or subversion of former conventions and a new form of interaction between multiple past and present references and discourses through fragmentation and the subsequent juxtaposition of contradictory allusions. On the other hand, the re-equation and reelaboration of these fragments in new formal arrangements was guided by the attempt to attain the timeless through fundamentals. In this endeavour, the past acquired ontological weight and symbolic dimensions. The focus on form as a bearer of meaning was a means to bring past and present together. This is expressed, for example, in the role attributed to myth, seen as a means to secure transhistorical and cross-cultural ties and to construct a new order through universal values.

Thus we find two complementary aspects of the fundamental involvement of history and tradition in modern art and architecture. On one level, the past provided modern aesthetics with raw material, i.e. with referents equated through their intrinsic and operative qualities independently of any historical or temporal sequentiality, which could be fused with present references through innovative creative processes. On another level, these processes were informed by a sense of the historical whole which established the basis of the modern narrative - a metanarrative that was humanistic in nature, operating as the lens through which past, present and future could be viewed.

Colin Rowe's seminal essay "The Mathematics of the Ideal Villa" (1947) marks the beginning of the debate on the first aspect-Le Corbusier's use of history as a source of architectural referents. Since then, criticism has continued to reveal how Le Corbusier's architecture constitutes a reelaboration of, rather than a rupture with, the past, extending Rowe's debate 
on the links with the "high" tradition of architecture to include antiquity, the idea of origins, and the vernacular. ${ }^{5}$

One milestone in this debate is Alan Colquhoun's 'Displacements of Concepts in Le Corbusier." Colquhoun characterized Le Corbusier's process of creation as a "displacement of concepts" which resulted from his approach to architecture as a work of art, consisting of an artistic reconciliation of opposites of two kinds. One kind of "displacement" occurred when elements of the "high" tradition of architecture were transformed, subverted and adapted to new solutions which contradicted their original use. In this process, the new was established with reference to a given tradition, knowledge of which was required in order to interpret its principles. To give one example, the rules prescribed in the "Five Points" entail a subversion of the tripartite division of podium, piano nobile, and entablature that characterizes the traditional articulation of building elements, and hence can only be fully understood with reference to the principles of classical composition.

Another kind of displacement consisted of the assimilation into architecture of elements outside this tradition. Summerson had already noted that Le Corbusier had found "fragments of real architecture" outside the traditional realms of the discipline. His modern buildings resulted from fusing fragments from the worlds of engineering, shipbuilding, industrial construction and aircraft. ${ }^{7}$ Continuing the thread opened up by Summerson, Colquhoun argued that Le Corbusier's works achieved a new unity by bringing together opposite self-referential concepts and attempting to resolve the conflict generated by their dialogical juxtaposition. The self-referential concepts ranged from the vernacular to those from the "high" tradition of architecture, from antiquity to contemporary works of architecture and engineering, and from modern construction techniques to industrial equipments, i.e. the processes and grammar of industrial production. ${ }^{8}$

In this artistic reconciliation of opposites, then, referents from the past and present were not only emptied of historical sequentiality, but their operative value was equally devoid of any disciplinary framework. 
The referents were not always submitted to such processes of "destruction" and "dismemberment," however, and many have noted how, in Le Corbusier's work, the past assumes other - perhaps more conventional-forms of allusion. This is markedly so from the 1930s onwards. If, as Rowe has noted, Palladio's geometrical and proportional principles surface only implicitly and fragmentarily at Garches, shifting from symmetry to asymmetry, the dwellings in the Plan Obus and Rio de Janeiro building-viaducts are a more direct reference to the loggias in the arcades in the port of Algiers. If, as Francesco Passanti has shown, the ceremonial dimension of architecture in the Villa Savoye aims to re-conceptualize the vernacular relationship between people and their artefacts through the concepts of Sachlichkeit and Typisierung, the skyscrapers in the Montevideo plan openly quote the interplay between the vertical architectural thrust and the horizontal expanse of water at the fortress of Negotin which Le Corbusier photographed on his journey to the East. ${ }^{9}$ And - one last example - if, as Jacques Lucan and others have noted, the projects for the Palace of the Soviets, the United Nations Headquarters and many of his buildings subversively translate the Piazza dei Miracoli in Pisa into compositions of free elements, the lighting towers at Ronchamp are a re-appropriation of the Serapeum at Hadrian's Villa. ${ }^{10}$

In order to characterize these comprehensive relationships between Le Corbusier's work and the past, Bruno Reichlin has borrowed the poststructuralist notion of intertextuality from hermeneutics. ${ }^{11}$ As in literature, every architectural creation consists of an elaborate process of cultural assimilation and transformation. Influence is the driving force behind artistic creation, establishing a dialogical relationship with existing works, whether through deformation, completion, rupture, re-appropriation or recreation. The sources of intertextuality extend far beyond architecture, ranging from the client and collaborators to the architectural programme, from folklore to real-world experiences, and from narratives and literature to the visual arts. ${ }^{12}$

Be it as it may, the modernist attitude towards the past is always framed by an undeniable attempt to escape from tradition. Yet the attempt itself 
Armando Rabaça

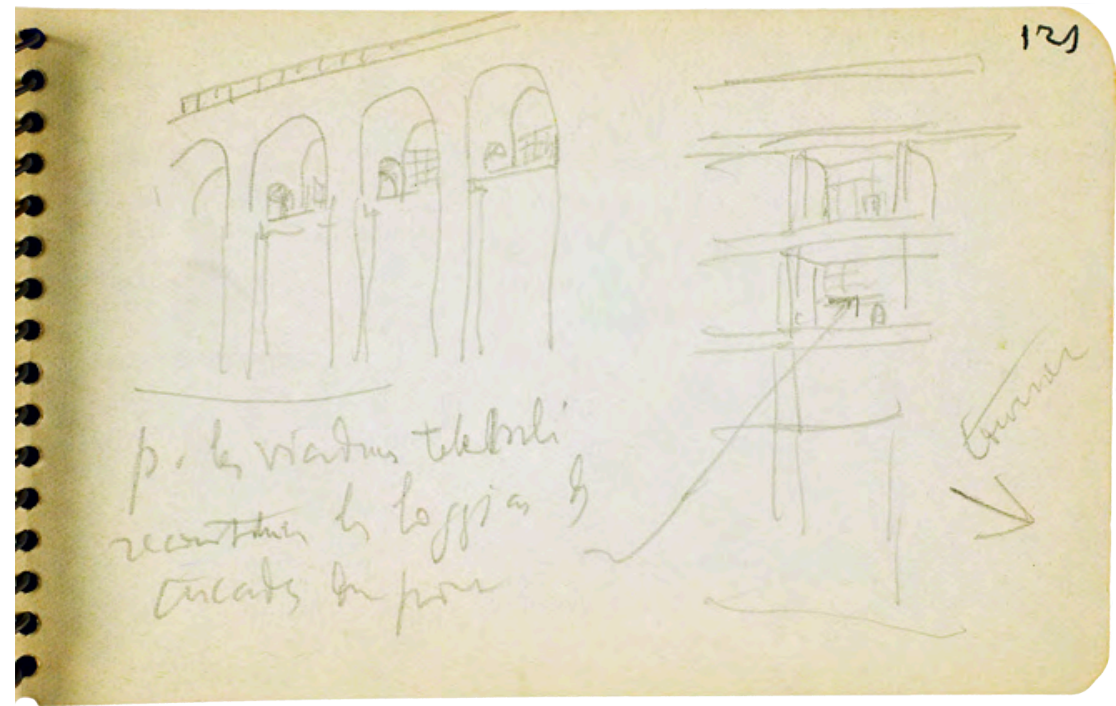

2. Le Corbusier

Sketch associating the dwellings in the Rio de Janeiro building-viaduct with the loggias in the arcades in the port of Algiers: "p. les viaducs telemli reconstituer les loggias des arcades du port"

Carnet C12, 121 (1936)

See also C12, 123

For Algiers see C10, n.p. 
constitutes a tradition, as Stanford Andersen has argued. Responding to Reyner Banham's critique of the Modern Movement for evidencing the influence of tradition, Anderson countered that the problem did not lie in seeing technology as the converse of tradition, but in recognizing a debt to the past without establishing it as an authority. The Modern Movement's attempt to shift from the authority of tradition to that of science and technology did not imply a rejection of the past, but a revised attitude towards it which had close affinities with the epistemology of science: the tradition of a critical attitude towards traditional theories in an attempt to address problems that older theories had been unable to solve. ${ }^{13}$

A similar position was held by Jürgen Habermas in the early 1980s. Reacting against the shift from the tradition of modernity to the postmodernist historicism of the works exhibited at the first Venice Architecture Biennale in 1980, Habermas noted that the term "modern" has appeared repeatedly in the history of Europe since antiquity whenever the consciousness of a new epoch is shaped through a renewed relationship with ancient civilisation. The difference in the twentieth-century modernist consciousness is that, rather than seeing antiquity as a model to be recovered through imitation, it established "an abstract opposition between tradition and the present" in an attempt to free itself from all historical ties. In this search for novelty through abstract opposition, Habermas concludes, the modernist consciousness preserves a secret tie to the past. ${ }^{14}$ It is this secret tie that we find, for example, in the tripartite composition underlying Le Corbusier's formulation of the Five Points. In short, the modernist tie to the past is essentially formalized through abstract aesthetics and principles, through which former conventions are subverted and re-elaborated in new formal arrangements.

The second aspect of the fundamental involvement of history and tradition in modern art and architecture - the search for the timeless through fundamentals - lies in the grand narrative of modernity: the belief in historical progress leading to a higher human condition. As the words of Eliot reveal, for modernism the past meant something deeper than just 
an escape from the impossibility of creating anew in a cultural void. The "grand narrative" of history provided the basis of modern architecture and its meaning, and in this meaning lay the message of modern art and architecture.

Postmodern discourses, rallying around the themes of history and tradition, claimed that architecture should have an allusive quality. A new communicative architectural language could be achieved by incorporating history and tradition into the realms of architecture, thus recovering recognizable forms by and symbolic dimensions broadly accessible to the populace. Reacting against the iconographic postmodernist exploration of architecture which would allegedly solve the semantically mute aesthetics of modernism, some have argued that the communicative dimension of modernist architecture went unnoticed by its critics. Modern architecture entailed a fundamental message that postmodernism failed to understand, namely that of a modern way of life, made possible by its functionalism and symbolically expressed through the aesthetics of the machine. ${ }^{15}$ Herein lay, for William Jordy, the unifying principle and essence of the modern movement of the 1920s: the aesthetics of the machine consisted of a symbolic objectivity, encompassing both the technological aspirations and the metaphysical essence of modernism. Modern architecture was not only deemed to be modern (functional, mechanically produced, etc.), but also symbolically modern. In this regard, it involved the symbolic objectification of past monuments, reducing them to their elemental qualities to create a primal architecture through which the past would literally be reborn. ${ }^{16}$

What distinguishes postmodernity from modernity is, in Jean-François Lyotard's analysis, the end of "grand narratives." 17 Whereas the view of modern architecture as semantically mute results from the postmodernist disbelief in metanarratives, for modernists the most profound role of the past lay in this comprehensive historical vision and the attempt to communicate it. Modern architects considered modern architecture to be redemptive, and because they believed in a higher human condition, their message would naturally be accessible to the common man. Their endeavour, idealistic as 
it was, involved communicating fundamentals through a new aesthetics, bringing the past and present together in an abstract, supratemporal language with universal meaning. The ultimate symbolic message of modern architecture was therefore the "grand narrative" of human history: the attainment of a higher human condition through the recovery of the timeless fundamentals of the past.

In order to understand this supratemporal, universal meaning, we have to look back at the preceding centuries. As the initial quotation from Goethe's Dichtung und Wahrheit indicates, the attempt to combine past and present in one in artistic creation was not new. In fact, the modernist historical consciousness can be traced back to a new historical vision that began to take shape in seventeenth- and eighteenth-century European thinking and that was consistently formulated in the nineteenth-century intellectual and spiritual revolution in Germany. ${ }^{18}$

Between the late eighteenth and early nineteenth centuries, the positivist concept of world history as a chronological process of cultural and social progress and straightforward narration from the religious to the secular began to be challenged by a new sense of historical development imbued with nationalist and spiritual tones. The classical view of universal values derived from Natural Law was replaced by the idea that values change in different historical and environmental contexts. Each society, culture, and nation was seen as a dynamic, "organic" whole, submitted to internal laws of development and moral and spiritual values. The universal ideal of classical art was replaced by the view of art as an expression of a particular people, their morals and life as a whole, and thus dependent on specific features such as climate, political constitution, national character and the spirit of the age.

A sense of universal history was nonetheless present in this relativist view of history and art, shaped by a transhistorical ontological idea which bound together the various different organic societies. In his "Über die Aufgabe des Geschichtschreibers" (1821), Wilhelm von Humboldt saw history as a chain of events linked in space and time. ${ }^{19}$ Although organic societies were governed by dynamic, internal processes, they were nevertheless subject to 
a more powerful active principle: original and eternal ideas which, although they were not directly visible since they lay beyond the finite, provided impetus and direction for world history. The historian's task was to reveal the essence of history by unveiling the $i d e a$ or hidden spirit beneath the surface of historical events.

The polarity between organic societies and the supranational cause was further developed by the historian Leopold von Ranke who, despite arguing that history should focus on particular societies and their individual innate laws, nevertheless had a sense of the historical whole. ${ }^{20}$ The individual (particular societies) and the general (the large-scale course of events) were inextricably interwoven, since although each society developed according to its own patterns and spiritual foundations, it was also subject to external influences which bound them together into one, defining the future of the western world. The historian therefore had to study each individual society whilst observing the large-scale course of events, examining the facts objectively but also seeking to capture the spirit of each society.

These discourses gave rise to the view of history as something endowed with a purposeful direction. The most extreme vision of the teleological view of history emerging from these pioneers can be found in Hegel's historical determinism. Despite the different variants of this historical reasoning, the essential is that the idealistic faith in a renewed western society that established the basis of the modern metanarrative rested on this sense of the historical whole and the belief in a transcendental, transhistorical idea that would unite individual societies.

One of Hegel's main opponents was Friedrich Nietzsche, whose ideas are of interest here due to the operative role he attributed to history. Drawing on Ranke's ideas, he criticized the excessive importance ascribed to history, seeing the nineteenth-century "consumptive historical fever" as inhibiting creative action, thus preventing the birth of modern culture. Writing in $O n$ the Uses and Disadvantages of History for Life (Von Nutzen und Nachteil der Historie für das Leben, 1874), Nietzsche argued for a critical history that was capable of examining the past and revealing its fundamental, suprahistorical values. ${ }^{21}$ 
The recovery of a living culture and the creation of "a unity of the artistic style in all expressions of the life of the people" were to be achieved through a re-elaboration of these suprahistorical values. "To be sure, we need history," Nietzsche argued, but "we need it for life and action," and in thus standing "in the service of life, it stands in the service of an unhistorical power," in a subordinate position that should not "be able to become pure science." The purpose of understanding the past is to "serve the future and the present," and this would be achieved by "being able to feel to a certain degree unhistorically." 22

Nietzsche was therefore paving the way for modernist thinking. He asserted that the goal of historical development should be the creation of a "living culture" rather than technology (a key feature of the Modern Movement greatly overlooked by canonical twentieth-century historians), argued for the operative quality of a non-authoritative history, and focused on "unhistorical" essentials. He looked to a suprahistorical time in search of an original living culture, finding its timeless essence in ancient Greece, as illustrated by his interpretation of the Greek tragedy in The Birth of Tragedy out of the Spirit of Music (Die Geburt der Tragödie aus dem Geiste der Musik, 1872).

The new historical consciousness of the late nineteenth century became characterized by the association between the notion of human progress and the idea of a supratemporal unity of past and present - despite the conflicting tension between nationalism and universalism, and however it varied between Hegel's historical determinism, Ranke's notion of an upward movement in which individual societies continuously shape general development in new ways, Goethe's notion of "circum-gress," or Nietzsche's concept of "eternal recurrence."

Through this nineteenth-century conception of history focused on supratemporal and cross-cultural values, on the one hand, and the Nietzschean operative role of history on the other, modernism could overcome Romantic eclecticism and shift from the formal attention to styles of past monuments towards their elemental qualities in search for a primal architecture; or as Jordy put it, towards symbolic objectivity. 
Eliot's words illustrate the legacy of these discourses in modern art. "The historical sense compels a man to write not merely with his own generation in his bones," he writes, "but with a feeling that the whole of the literature of Europe from Homer and within it the whole of the literature of his own country has a simultaneous existence and composes a simultaneous order." As for Le Corbusier, I have discussed elsewhere how he absorbed this nineteenth-century historical vision in a consistent way through books such as Edouard Schuré's Santuaires d'Orient (1898), which he read in 1908, and how his subsequent autodidactic agenda was driven by this. ${ }^{23}$ Nietzsche was another key influence: by the same time, he had also read Thus Spake Zarathustra and been struck by Nietzsche's concept of the Übermensch and its allegorical representation of a higher human condition. ${ }^{24}$

From this early period onwards, history signified an ongoing process of cultural and social progress for Le Corbusier, driven by a transhistorical, ontological idea binding together the history and traditions of various different organic societies. The transcendental status of the idea which was to unite societies in a living cultural whole implied an original existence which was to be retrieved to renew life in a unified modern society. Thus he saw modern architecture as a "broad emerging crusade towards the universal thought" envisaging a "millennial relationship between man and nature." 25 This view was informed by the operative quality of history. Although artistic expression in the various organic societies and cultures differed, they nonetheless shared this ontological idea. In expressing this supratemporal essence, they were all equally valid sources for the creation of a new artistic expression. Hence Le Corbusier's interest in Greek, Roman, Byzantine, Gothic and peasant art and architecture; hence his interest in ancient mythology, a primal expression of the idea. Historical destiny, as Schuré put it in Sanctuaires, would be achieved by applying the old traditions and symbols to a new universal meaning. ${ }^{26}$ This goes without saying that the artist had a key role in this humanist task: it is well known that Le Corbusier thought of himself as a redeemer of society and that this Nietzschean idea of the artist was first assimilated during this early period. ${ }^{27}$ 
Thus we find three complementary aspects in Le Corbusier that were inherited from nineteenth-century historicism: (1) a faith in and focus on an emerging future, understood as part of a historical evolutionary process, (2) a relativistic view of history in which art is an expression of the internal cultural laws of each society, which nonetheless share transhistorical and universal essentials, (3) the belief that these essentials, in relating to an original existence, were more faithfully expressed in the art of ancient civilizations and vernacular artefacts. Le voyage utile, a sketch by Le Corbusier published in L'Art décoratif d'aujourd'hui showing the itinerary of his educational trips between 1907 and 1911 (from Tuscany to Paris, Germany, and the journey to the East) reflects these three aspects under the labels of culture, folklore, and industry. ${ }^{28}$ Industry stands for the future of western civilization, culture for the high achievements of art history in the large-scale course of events, and folklore for vernacular art, expressing particular "organic wholes" within the course of the history of civilization, still uncorrupted by industrialization. ${ }^{29}$ All these were framed, for Le Corbusier, by a common historical sense.

In the light of this idealist legacy, it becomes clear that the diverse aesthetic expressions in Le Corbusier's work throughout his career are united by a common historical vision and essential attitude towards the past. The machine aesthetics of the 1920s aimed to convey the new historical era of the second machine age through symbolic objectivity. From the 1930s onwards, well before the postmodernist turn, this became informed by new aesthetic expressions associated with notions such as tradition, the primitive, or the vernacular, evident in works such as the Maison de Mandrot, the Swiss Pavilion at the Cité Universitaire in Paris, or the Petite Maison de Weekend in Celle-St-Cloud. This transitional period led to his subsequent work which reflects a growing focus on myth, as illustrated in the paradigmatic examples of the Unité d'Habitation in Marseilles, Ronchamp, and Chandigarh. The layering of fragments and their dialogical juxtaposition remained a characteristic of these works, with their mytho-poetic allegorical qualities still aiming for a primal universal language as much as the machine aesthetics of the $1920 \mathrm{~s} .{ }^{30}$ All these aesthetic differences moved in one single direction, 


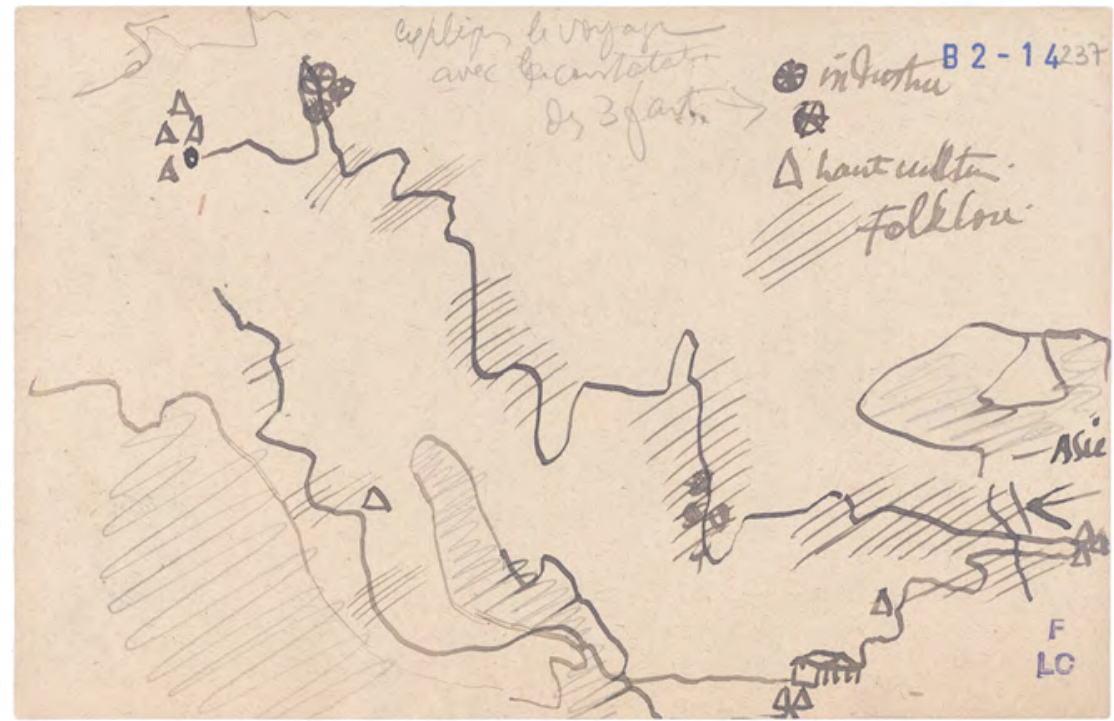

3. Le Corbusier

Le voyage utile.

Sketch showing the itinerary of

Le Corbusier's formative trips, labeled with three categories:

industry, "high" culture, and folklore.

A similar version was published in

L'Art décoratif d'aujourd'hui (1925) 
bound by the same fundamental creative process and philosophical idealistic positioning. Herein lies the fundamental meaning of history and tradition for Le Corbusier. The message of the symbolic objectivity of the 1920s and the later infatuation with the primitive, the archaic and the mythical is essentially the same: the renewal of human condition through the search for the timeless. Le Corbusier remained, in this sense, deeply modern. As Gianni Vattimo stated, for the moderns, the new was legitimated through a process of "appropriation and re-appropriation of its own "foundations," often understood as "origins," presenting itself as 'recovery', rebirth, or return. ${ }^{31}$

\section{Contributions to the Debate}

The essays gathered here contribute, in different ways, to the ongoing research into Le Corbusier's relationship with history and tradition. They explore particular episodes which bring to light both the operative role of the past in his creation of a new abstract synthesis and his modernist historical consciousness. The legacy of nineteenth-century historicism and idealism is particularly explicit in the two opening essays. Ivan Zaknic offers a comparative analysis of Le Corbusier's Voyage d'Orient and the journal of his travelling companion August Klipstein, revealing that the friendship between Le Corbusier and the art historian nurtured the influence of nineteenthcentury German historicism in Le Corbusier during their 1911 trip. Klipstein believed that artistic traditions and styles should be juxtaposed, compared and interpreted using philosophical-aesthetic principles rather than in strict historical terms. His arguments echoed Worringer-under whom he studied - and his view of art as an expression of the psychological needs of a given organic society, which allowed him to assert that figurative and abstract categories are timeless and reflect different psychological worldviews, rather than being forcibly submitted to temporal sequentiality. While, as Zaknic argues, Klipstein helped Le Corbusier to objectify his "unstructured, sensual receptivity to his surroundings," it is clear that, for Le Corbusier, 
Klipstein's - and Worringer's - philosophy of art meant the consolidation of Schuré's discourse, his assertions about supratemporal values shared by artistic expression in different epochs, the historical relativism associated with this, and the psychological-experiential dimension of art. In short, his friendship with Klipstein helped pave the way for a creative process of abstract synthesis involving judiciously selected fragments, independently of historical sequentiality.

This way of looking at different artistic expressions is further explored in Arthur Rüegg's contribution. Rüegg investigates Le Corbusier's intimate world, showing how the selection and display of Le Corbusier's collection particulière in his Parisian apartments was not subjected to chronological criteria. Objects representing different worlds instead find affinities through their aesthetic qualities and meaning. The worlds of primitive, archaic, and vernacular objects, expressing collective memories - some of which collected during the journey to the East - share transhistorical values with contemporary art. The gradual development of a "technique of grouping" these objects by recognizing "patterns of unity across time," and the understanding of a process of formal perfection over time through use and serial production, operating on a conceptual and formal level, illuminate the nature of a design strategy based on the "displacement of concepts" which ultimately resolves the opposition between tradition and utopia.

The third essay discusses monastic life, another concept displaced by Le Corbusier. David Leatherbarrow shows how, for Le Corbusier, the belief in a higher human condition underlying the modern metanarrative was reflected in the search for an ideal way of life. Leatherbarrow also reveals the extent to which, for Le Corbusier, utopia was humanist rather than technological in nature. The significance Le Corbusier attributed to monastic life developed from his 1907 visit to the Carthusian Monastery in Il Galluzzo, in val d'Ema, and has been discussed by other historians. ${ }^{32}$ Leatherbarrow revisits this subject, showing that the individual-collective complementarity pursued and the way of life envisaged by Le Corbusier reinterprets a historical pattern that traverses the tradition of western monastic culture: the rejection of 
contemporary culture, recovery of fundamental experiences through retreat, and re-articulation of a new way of life and balance between personal and communal life. It is a tradition that is revealed both in sacred and secular terms. This link to the past, the author concludes, is just one of the many ways in which modern architecture built upon history and tradition, as exemplified in the continuity of spatial ordering principles, building techniques, and even adaptation to the historical legacy of building location.

The two contributions which follow focus on specific aspects of the operative role of the past in Le Corbusier's work, one devoted to urban design and the other to architecture. Christoph Schnoor approaches the issue of town planning to show how, in this respect, Le Corbusier also instrumentalized history in his attempts to understand urban design. Schnoor focuses on the period between 1910 and 1915, when Le Corbusier acquired the basis for his future urban visions, revealing the operative value that he attributed to history. His research into urban history and theory during this period reveals his interest in principles through which the problems of the contemporary city could be addressed rather than in historical narratives. It was this interest in principles that enabled him to maintain and reconcile arguments pertaining to opposite aesthetic attitudes within the contemporary urban debate to which he was exposed. As the author shows, the categories of the picturesque and the monumental were gradually and simultaneously assimilated through these discourses and never completely discarded in Le Corbusier's work and ideas. On the contrary, ambivalences were part of his artistic conception.

With Francesco Passanti the focus shifts to the field of architectural space. One of the key aspects of the debate on urban design that influenced Le Corbusier during his research in Germany in 1910-1911 was, as Schnoor shows, the notion of space. Le Corbusier's approach to architecture gained a perspective on space during the 1911 journey to the East, influenced by the Sittesque debate on urban design. Passanti shows how this early attention to architectural space was assimilated and re-elaborated in his architectural explorations in the 1920s. The tension between continuity and individual 
parts in Le Corbusier's architectural space was conceptualized by combining historical references, such as Pompeian villas and Hadrian's Villa, with the modern aesthetic discourses of Cubist painting and Symbolist poetry. The operative role of history in this process of synthesis through the combination of different references and discourses evolved from the notion of centrality to one of continuity achieved through the play of spatial volumes. This is demonstrated through the analisys of Le Corbusier's early sketches and architectural works and some of his villas of the 1920s, namely the Maison Cook, the Villa La Roche-Jeanneret and the Petite Maison in Vevey. Yet it brings to light the spatiality of perhaps even more puzzling cases, such as that of the Villa Stein's main floor.

In this demonstration of the operative role of history in Le Corbusier's spatial conception there is also a suggestion of the legacy of nineteenthcentury historicism: the Petite Maison, as Passanti argues, illustrates how the play of spatial volumes is given symbolic and emotional meaning through the continuous ribbon window, which internalizes a contemplative landscape that evokes a primeval existence.

The extent to which the nineteenth-century tension between the idea of an evolving universal history and the specificity of organic societies and cultures - with obvious nationalist contours - endured in Le Corbusier's work surfaces in Johan Linton's essay. The universalizing nature of Le Corbusier's call for a new modern architecture and society scarcely needs to be mentioned. Yet he saw France as a leading culture and, as Linton shows, his early attraction to French culture and the city of Paris soon became a reference point for his theoretical and architectural work. Linton thus expands Schnoor's arguments on Le Corbusier's early adherence to French urbanism. The comparison between Le Corbusier's readings on French architecture and his writings and arguments shows that the proclaimed rupture with the models of the past accompanied his lifelong attempt to align with the French cultural heritage. Le Corbusier thought of himself and his own work as a rebirth of "the spirit of the French genius," continuing a tradition which, establishing autonomy from Italian art, linked the Abbé 
Marc-Antoine Laugier to Viollet-le-Duc, Louis XIV to Napoleon III, and André Le Nôtre to Baron Haussman.

The continuing influence of history and tradition in Le Corbusier's late career is highlighted in the two concluding essays. Stanislaus von Moos provides us with a perceptive discussion on the period following World War II, characterized by the crisis in modern architecture and the emerging debate on the communicative capacity of architecture. This essay illuminates the extent to which Le Corbusier's historical vision remained unchallenged and how he remained deeply modern. With a truly modernist faith in the future - the same faith underlying the tabula rasa proposed in the 1920s - Le Corbusier saw the destructive consequences of World War II as an opportunity for the rebirth of a new civilization. The Platonic volumes of purism of the 1920s had given way to an expressive, symbolically charged language which, rather than following the emerging discourse on the aesthetic demands of ordinary people, found affinities with the "primitivism" and mythic allegories of Picasso's work. Similarly, he maintained his Nietzschean stance as the redeemer artist against the advocates of collective participation, seeing architecture as a redemptive art, as iconographically illustrated by the "Open Hand." Even if, as von Moos argues, there is no simple key to deciphering the mytho-poetic quality of his late work, it seems clear that Le Corbusier was still in search of a primal universal idiom through the recovery of transhistorical, universal values.

María Candela Suárez's essay, in turn, explores the design for the Villa Hutheesing-Shodhan in Ahmedabad. Suárez shows how the modern architectural lexicon that Le Corbusier developed and consolidated during his life was re-elaborated at a late stage through his contact with Indian architecture and culture. On the one hand, Indian tradition played an operative role in his relentless research, as demonstrated by the development of architectural elements such as the brise-soleil, redesigned through Indian tradition in order to adapt to the local climate and way of life. In Rüegg's words, the brise-soleil, is subjected to a process of formal and conceptual perfection through Indian tradition. On another level, for Le Corbusier India 
meant a reencounter with an essential and timeless world and a spiritual way of life of a mythic past, bringing him back to his 1911 trip with Klipstein.

In short, the contributions to this book reveal the ongoing, vital significance of history and tradition in Le Corbusier's work, from his early study trip to the East to his late works in India. In accepting the fundamental role that history and tradition played in Le Corbusier's work, and given the complexity and richness of his creative process, a book of this nature cannot attempt a comprehensive approach to the subject. The essays gathered here are only fragments of the still developing story of Le Corbusier's modernism. Nevertheless, they illustrate how the past participated in the modernist creative process of abstract art, from the 1920s machine aesthetics to the late infatuation with myth. They also shed light on the extent to which the operative quality of the past was framed by a comprehensive historical vision that took the form of metanarrative. Neither the analytical studies on Le corbusier's architecture nor the synthetic approaches to his philosophical thinking - nowadays involving countless inflammatory discourses on his political agenda - should dismiss such a historical vision, a quintessential characteristic of modernity, as Lyotard put it, which is crucial to understanding modernism in general and Le Corbusier in particular.

\section{Notes}

The idea for this book originated from two lectures on Le Corbusier, one by Francesco Passanti and the other by Arthur Rüegg, presented at the Department of Architecture of the University of Coimbra in July 2014. Although their subjects were different, both emphasized the significance of the past in Le Corbusier's work. I am deeply grateful for their enthusiasm and commitment to this publication. I am equally most thankful to all the contributors for accepting to embark on this project. Warm thanks to Nuno Nina from Nozzle for the unconditional support in test prints. 


\section{Le Corbusier, History and Tradition}

1 The literature is extensive. See, for example, on Aalto, Raija-Liisa Heinonen, "Some Aspects of 1920s Classicism and the Emergence of Functionalism in Finland," in David Dunster, ed., Alvar Aalto, Architectural Monographs 4 (London; New York: Academy Editions; St. Martin's Press, 1988), 20-27; on Oud, Stanford Anderson, "The Vernacular, Memory and Architecture," in Maiken Umbach and Bernd Hüppauf, eds., Vernacular Modernism: Heimat, Globalization, and the Built Environment (Stanford, California: Stanford University Press, 2005), 157-171; on Mies, Wolf Tegethoff, "Catching the Spirit: Mies's Early Work and the Impact of the 'Prussian Style," in Terence Riley and Barry Bergdoll, eds., Mies in Berlin (New York: The Museum of Modern Art, 2001), 134-152.

2 John Summerson, "The 'Poetry' of Le Corbusier," Architect and Building Newes (April 1940), repr. in Irena Murray and Julian Osley, eds., Le Corbusier in Britain: An Anthology (Abington, Oxon, New York: Routledge, 2009), 117-21. See also Summerson's "Architecture, Painting and Le Corbusier," (1947) in Heavenly Mansions and Other Essays on Architecture (New York and London: W. W. Norton \& Company, 1963), 177-94. Le Corbusier himself self-indulgently acknowledged Summerson's view. See his sketchbook F24, 14-15, from 1951, repr. in Françoise de Franclieu, ed., Le Corbusier: Sketchbooks 1950-1954, vol. 2 (Cambridge, Mass. and London; New York: MIT Press; Architectural History Foundation), ills. 710, 711.

3 Summerson, "Architecture, Painting and Le Corbusier,"189-190.

4 Ibid., 191-192. For an acute discussion on the links between Le Corbusier's architecture, his paintings and cubism see Bruno Riechlin, "Jeanneret-Le Corbusier, Painter-Architect," in Eve Blau and Nancy J. Troy, eds., Architecture and Cubism (Cambridge, Mass.: MIT Press, 2002), 195218.

5 Colin Rowe's "The Mathematics of the Ideal Villa" (1947) was followed by "Mannerism and Modern Architecture" (1950). They were both reprinted in Rowe, The Mathematics of the Ideal Villa and Other Essays (1976; repr., Cambridge, Mass.: MIT Press, 1987), 1-27, 29-57. The literature is too vast to list here, although some key texts in addition to Rowe should be mentioned. On antiquity see Kurt Forster, "Antiquity and Modernity in the La Roche-Jeanneret Houses of 1923," Oppositions, no. 15-16 (Winter/Spring 1979): 131-53; on the vernacular the seminal work is Francesco Passanti, "The Vernacular, Modernism, and Le Corbusier," The fournal of the Society of Architectural Historians 56, no. 4 (December 1997): 438-51, and a different version of this essay published in Umbach and Hüppauf, Vernacular Modernism, 141-56, a book offering a broader approach to modernism and the vernacular. For an overall view see Pierre Saddy and 
Armando Rabaça

Claude Malécot, eds. Le Corbusier, le passé à réaction poétique, exb. cat. (Paris: Caisse nationale des Monuments historiques, Ministère de la Culture et de la Communication, 1988); Stanislaus von Moos and Arthur Rüegg, eds., Le Corbusier before Le Corbusier. Applied Arts, Architecture, Painting, Photography 1907-1922 (New Haven and London: Yale University Press, 2001); Danièle Pauly, ed., Le Corbusier et la Méditerranée (Marseille: Éditions Parenthèses, Musées de Marseille, 1987); Marida Talamona, ed., L'Italia di Le Corbusier (Milan: Electa, 2012); Giuliano Gresleri, Le Corbusier, viaggio in Oriente. Gli inediti di Charles-Edouard Feanneret fotografo e scrittore (Venice: Marsilio, 1985), and the extensive literature on the journey to the East published in more recent years.

6 Alan Colquhoun, "Displacements of Concepts in Le Corbusier," Architectural Design 43 (April 1972): 220-243, repr. in Essays and Architectural Criticism: Modern Architecture and Historical Change, Oppositions Books (Cambridge, London: MIT Press, 1991), 51-66.

7 Summerson, "Architecture, Painting and Le Corbusier," 192.

8 Colquhoun, "Displacements of Concepts."

9 Passanti, "The Vernacular, Modernism, and Le Corbusier."

10 Jacques Lucan, “Athènes et Pisa. Deux modèles pour l'espace convexe du plan libre," Les Cahiers de la recherche architecturale et urbaine, no. 22-23 (February 2008): 59-78. See also Lucan's Composition, Non-composition: architecture et theories, $\mathrm{XIXe-XXe} \mathrm{siècles} \mathrm{(Lausanne:} \mathrm{Presses} \mathrm{polytechniques} \mathrm{et}$ universitaires romandes, 2009), esp. 349-65. The comparison between Pisa, the Palace of the Soviets and the United Nations Headquarters was advanced by Le Corbusier himself in his book Le Modulor (Boulogne: Éditions de l'Architecture d'haujourd'hui, 1950), 167-169.

11 Reichlin, "Introduction: Architecture et intertextualité," Les Cahiers de la recherche architecturale et urbaine, no. 22-23 (February 2008): 11-20.

12 Ibid., "L'œuvre n'est plus faite seulement d'elle-même," 119-50.

13 Anderson, "Architecture and Tradition That Isn't 'Trad, Dad," in The History, Theory and Criticism of Architecture, papers from the 1964 AIA-ACSA Teacher Seminar, Cranbrook, ed. Marcus Whiffen (Cambridge, Mass.: MIT Press, 1965).

14 Jürgen Habermas, "Modernity - An Incomplete Project," in Hal Foster, ed., The Anti-Aesthetic. Essays on Postmodern Culture (Washington: Bay Press, 1983), 3-15.

15 Anderson, "The Fiction of Function," Assemblage, no. 2 (February 1987): 18-31.

16 William H. Jordy, "The Symbolic Essence of Modern European Architecture of the Twenties and Its Continuing Influence," The fournal of the Society of Architectural Historians 22, no. 3 (October 1963): 177-87. 


\section{Le Corbusier, History and Tradition}

17 Jean-François Lyotard, The Postmodern Condition: A Report on Knowledge, trans. Geoff Bennington and Brian Massumi (Manchester: Manchester University Press, 1984). Originally published in French as La condition postmoderne: rapport sur les savoir (1979).

18 On the nineteenth-century German historical conception and its predecessors, see Friedrich Meinecke, Historism: The Rise of a New Historical Outlook (New York: Herder and Herder, 1972); Georg G. Iggers, The German Conception of History: The National Tradition of Historical Thought from Herder to the Present, rev. ed. (Middletown, Connecticut: Wesleyan University Press, 1983).

19 Wilhelm von Humboldt, "Über die Aufgabe des Geschichtschreibers" (1821), translated into English as "On the Historian's Task," History and Theory 6, no. 1 (1967): 57-71.

20 On Ranke see Meinecke, Historism, 496-511.

21 Friedrich Nietzsche, "On the Uses and Disadvantages of History for Life," in Daniel Breazeale, ed., Friedrich Nietzsche, Untimely Meditations (Cambridge: Cambridge University Press, 1997), 57-124.

22 Ibid., $57 \mathrm{ff}$.

23 Armando Rabaça, "The Philosophical Framework of Le Corbusier's Education: Schuré and German Idealism," in Jorge Torres Cueco, ed., Le Corbusier, 50 Years Later (Valencia: Editorial Universitat Politècnica de València, 2015), 1765-83. http://dx.doi.org/10.4995/ LC2015.2015.671. Edouard Schuré's Santuaires d'Orient is a paradigmatic and important case because it expounds this German idealistic historical vision in a clear and operative way. Yet this was a widespread vision that characterized the turn of the century, which was expressed in different degrees in other sources available to Le Corbusier during his formative years. These sources, which were preparatory to his reading of Schuré, range from practical design sourcebooks such as Owen Jones's The Grammar of Ornament (1856) to literature on art theory and general philosophical questions such as Henry Provensal's L'Art de demain: vers l'harmonie intégrale (1904) and Charles Blanc's Grammaire des arts du dessin, architecture, sculpture, peinture (1867). On the influence of Provensal in Le Corbusier, see Paul Venable Turner, The Education of Le Corbusier (New York: Garland, 1977), 10-24. For Blanc see Passanti, "The Aesthetic Dimension in Le Corbusier's Urban Planning," in Eric Munford, Hashim Sarkis, and Neyran Turan, eds., fosep Lluís Sert: The Architect of Urban Design, 1953-1969 (New Haven and London: Yale University Press, 2008), esp. 28, 36n8; Idem., "Toscane," in Talamona, ed., L'Italie de Le Corbusier, XVe Rencontres de la Fondation Le Corbusier (Paris: Fondation Le Corbusier, Éditions de La Villette, 2010), 25-26. During the subsequent period in Paris (1908-1909), Le Corbusier consolidated 


\section{Armando RabaçA}

the deterministic views of history in the field of architectural history through authors such as Viollet-le-Duc, Auguste Choisy and Edouard Corroyer. See Rabaça, "Ordering code and Mediating Machine. Le Corbusier and the Roots of the Architectural Promenade," (Doctoral thesis, Coimbra University, 2013), 99, 117-131, passim.

24 On Le Corbusier and Nietzsche see Turner, The Education of Le Corbusier, 56-61; Jean-Louis Cohen, "Le Corbusier's Nietzschean Metaphors," in Nietzsche and "An Architecture of Our Minds," ed. Alexandre Kostka and Irving Wohlfarth (Los Angeles: Getty Research Institute, 1999), 311-332; Charles Jencks, Le Corbusier and the Continual Revolution in Architecture (New York: The Monacelli Press, 2000), 354-355; H. Allen Brooks, Le Corbusier's Formative Years: Charles-Edouard Feanneret at La Chaux-de-Fonds (Chicago: University of Chicago Press, 1997), 174-175.

25 Le Corbusier, Croisade; Ou, le crépuscule des académies (Paris: G. Crès, 1933), 17-18, 25-26.

26 See Rabaça, "The Philosophical Framework of Le Corbusier's Education."

27 See note 24.

28 Le Corbusier, L'Art décoratif d'aujourd'hui (Paris: G. Crès, 1925), 216.

29 The extent to which the association between vernacular art and the notion of the "organic whole" lingered in Le Corbusier can be seen, for instance, in his book Manière de penser l'urbanisme (Boulogne: Éditions de l'Architecture d'aujourd'hui, 1946), 180. The main discussion is still Passanti's "The Vernacular, Modernism, and Le Corbusier."

30 See Stanislaus von Moos's essay in this volume.

31 See Gianni Vattimo's introduction to The End of Modernity: Nihilism and Hermeneutics in Post-Modern Culture, trans. Jon R. Snyder (Cambridge: Poilty Press, 1988), 1-15.

32 The significance of monasticism in Le Corbusier's work has been discussed by several authors since Peter Serenyi, "Le Corbusier, Fourier, and the Monastery of Ema," The Art Bulletin 49, no. 4 (December 1967): 277-86. See, for example, von Moos, Le Corbusier, Elements of a Synthesis, rev. ed. (Rotterdam: 010 Publishers, 2009), 140-143, originally published in German as Le Corbusier. Elemente einer Synthese (Frauenfeld: Huber Verlag, 1968); Ivan Zaknic, "Epiphany on Mount Athos," Fournal of Architectural Education 43, no. 4 (Summer 1990): 27-36 and the passage about Le Corbusier's attraction to ascetic life in his essay in this volume; Passanti, "Toscane," 22-23. 